\title{
India's Agni Missile Systems: Strengthening India's Nuclear Deterrence
}

\author{
Debalina Ghoshal ${ }^{*}$
}

\begin{abstract}
Over the years, India has been able to acquire a credible minimum nuclear deterrence. In this, the Agni missile system is integral to India's counter second-strike capability especially against China. The Agni category missiles are solid propelled ballistic missiles, ranging from short range missiles to intermediate range missiles (700-5000kms) with road and rail mobility providing greater chances of survivability during an enemy attack. This strengthens its scope of launching a counter/second strike. This makes India one of the few countries in the world with the ability to potentially decapitate its enemy by preserving its arsenal in the first attack from the enemy. This article provides a deep analysis of India's Agni missile systems.
\end{abstract}

Keywords: Agni Missiles, Nuclear Detterance, Inter-Continental Range

\section{Introduction}

Ever since India conducted the nuclear tests in 1998, focus has been on strengthening the nuclear deterrence posture and chalking out a nuclear strategy. Over the years, it shifted from liquid-fuelled ballistic missiles to solid fuelled ones, concentrated on developing

* Independent Consultant based in New Delhi. She frequently writes for the Week on missile defence system, debalinaac.87@gmail.com 
nuclear capable cruise missiles as well as worked towards achieving a sea-based deterrent in order to strengthen its counterstrike/ second-strike capability. The Agni category missiles are solid propelled ballistic missiles ranging from short range missiles to intermediate range missiles $(700-5000 \mathrm{kms})$ with road and rail mobility providing greater chances of survivability during an enemy attack. This strengthens India's 'no-first use' policy, mentioned in India's nuclear doctrine.

India's nuclear strategy relies on a 'credible minimum deterrence' (Rajaraman, 2014) posture for which the Agni category missile systems are best suited. They form the backbone of India's landbased nuclear deterrence. In addition, there are reports that the Agni-V would be equipped with multiple independently targetable re-entry vehicle (MIRVs) thereby further increasing its deterrent value. However, it has also attracted concerns from around since MIRVs, according to Cold War literature, are first-strike weapon systems.

In addition, India follows a posture of recessed deterrence whereby warheads are de-mated from their delivery systems. However, in the recent past, there have been reports that the Agni-V would be canister launched; that is, warheads would need to be mated with delivery systems. Mated weapon systems bring in added burden on command and control system and also raises the risk of launch on warning $(\mathrm{LoW})$. All these factors result in the need to analyse the role of Agni category missiles, its deterrent value vis-à-vis Pakistan and China as well as the future nuances that could affect India's nuclear deterrence.

\section{History of Agni Missiles}

The Agni missile is a component of the Integrated Guided Missile Development Program (IGMDP) that was launched by India in 1983 with a budget of $\$ 260$ million and managed by Defence Research and Development Laboratory (DRDL). The Agni category missiles were to use the Indian Space Research Organisation (ISRO) developed solid fuelled engines as opposed to the Prithvi category missiles that used the Devil Technology. In 1989, India test fired Agni category missile that had a range of $1000-1500 \mathrm{kms}$. It was the 
Agni I category missile that was test fired, providing evidence of establishing re-entry technology and precise guidance to reach the specific target (The Economic Times, 2013). The first stage of the solid fuelled booster motor of the Satellite Launch Vehicle (SLV-3) was used for the first stage of the two-staged Agni missile. After the missile was successfully test fired in 1989, the then Prime Minister, Rajiv Gandhi declared, "the technologies proved in Agni are deeply significant for evolving national security options" (Bobb, 1989). At the same time, he was careful to call Agni a "technology demonstrator" and not a weapon system." However, the missile did raise concerns in the United States especially as India had conducted the Peaceful Nuclear Explosion (PNE) in 1974 and its plutonium resource could be used to make bombs. Hence, the Indian Government also clarified, "Technology has improved missile accuracy dramatically. As accuracy improves, the nuclear yield needed to destroy hard military targets also drops dramatically, to the point where conventional warheads could do the job" (Bobb, 1989).

Though the Agni category missile underwent tests in 1992 and 1994, the Agni project was stalled for a while and the operational version of the missile was first tested in 1999. One of the reasons for stalling the project was probably because of the US pressure imposed on India to stop the development of the Agni missile system. The revival of the programme was because of the conduction of the 1998 nuclear tests as there was a need to develop delivery mechanisms for India's nuclear warheads. However, prior to the nuclear tests in 1998, while many had thought that India had given up its Agni missile, A.P.J. Abdul Kalam who was in charge of the missile development program requested journalists, "please also don't write we have given up Agni. Because that will demoralise a lot of my people"(Prasannan, 2015). On why the missile was not being tested any more, he clarified, "Look, what should be the warhead of a weapon like this? Why should I send a few tonnes of TNT over 1500kms? The weapon's payload has to be nuclear...But I don't have it. It's for the cabinet to decide when to have the nuclear warhead. Till they decide, I have nothing more to do with the missile...Every time I test (the Agni), I am burning up costly hardware which I can't afford. So I had packed more than 
600 parameters in three tests. My missile is ready" (Prasannan, 2015).

As a result of this, following the test of Agni-I but India started concentrating on advanced versions of the Agni-1 and in 1999, India under the auspices of the Defence Research and Development Organisation (DRDO), test fired the Agni-II medium range ballistic missile with improved guidance system with a range of $2000 \mathrm{kms}$. With Agni II, India took a great leap in missile technology. While the earlier version, Agni-I, used liquid fuel in the first stage and solid in the second, Agni-II used solid fuel in both the stages, thereby, drastically cutting down preparation time for launching the missile that enabled India to move closer to developing a 'credible' counter strike capability.

India's constant development of Agni category missiles resulted in Pakistan too hastening with its missile development programme and following the test firing of Agni-II, Pakistan despite international plea for restraint, tested in 1999, the liquid fuelled medium range Ghauri missile and solid fuelled short range Shaheen-1 missile (Arms Control Association, 1999).

The Agni-I and Agni-II underwent several tests since then in order to ensure the operational readiness of the missiles. In 2004, the Agni-I missile was successfully inducted into the Indian Army (Taneja, 2018). Even after the induction, Agni-I had undergone several tests to check its operational readiness. The Agni-II entered service in 2004. However, due to failed tests and technical issues, Agni-II achieved operational capability only in the year 2011 (Missile Threat, 2016). In fact, 2011 was a landmark year for India's nuclear deterrence as it was in the same year that the intermediate range Agni-III was also inducted in the Indian Army (News 18, 2017). The Agni-III with a range of $3000 \mathrm{kms}$ underwent the first trial test in the year 2006 but there were several problems during the test and hence, the missile underwent its second test in 2007. Agni-III was developed owing to the need to develop long range missile system with deep strike capability against China that could hold major Chinese cities under threat.

However, despite the fact that India had developed Agni-III with a range of $3000 \mathrm{kms}$, they still needed to develop a longer range 
capability that could have greater ability to strike deep within China. This led to the development of the Agni-IV intermediate range ballistic missile. The missile had a range of $4000 \mathrm{kms}$ and was tested in 2011, 2012, twice in 2014, once in 2015 and once in 2017 (Subramanian, 2017). India's desire to achieve inter-continental range capability further led India to develop the Agni-V missile with a range of $5000 \mathrm{kms}$. However, there are reports that the missile has been kept on depressed trajectory to restrict the range to $5000 \mathrm{kms}$. Nevertheless, the 2012 Agni test became a milestone achievement for India's nuclear deterrence and according to the then Prime Minister, Manmohan Singh, the test was "another milestone in our quest to add to the credibility of our security and preparedness and to continuously explore the frontiers of science" (Auner, 2012).

There are assumptions that the Indo-US nuclear deal led to the restriction of the range of the Agni-V missile. In fact, Chinese media has reported the missile to have a range of $9000 \mathrm{kms}$ and that according to them, India has kept the range of the missile restricted to $5000 \mathrm{kms}$ due to US and NATO pressure. (The Economic Times, 2012). There are also reports that the range of the missile was strategically delayed by India to secure its membership into the Missile Technology Control Regime (MTCR) (Ranghuvanshi, 2016). The Agni-V underwent 'developmental trials' with 'open configuration tests' in the year 2012 and 2013 and later in the years 2015 and 2016, the missile underwent test fire from hermitically sealed canisters (Pandit, 2018).

\section{Technical Parameters of Agni Category Missiles}

Agni-I: the missile is a single stage short range ballistic missile system with a specialised navigation system that can reach the target with a high degree of accuracy and precision. The missile can carry payload up to $1000 \mathrm{kgs}$ (The Hindu, 2018). The upper stage of the missile is a liquid propulsion system while the lower stage is solid propulsion and the missile was derived from Prithvi with a strap down inertial navigation system that adopts explicit guidance. Carbon composite structures are used in the missile for protection of the payload. In its present form, the missile is expected to reach targets within $700 \mathrm{kms}-900$ of range (Taneja, 
2018a). It is capable of being launched from rail based as well as road based mobile launchers. There are also reports that Agni-I had undergone significant modifications and improvements in its reentry technology and maneuverability (Rout, 2010). The missile did not have fins.

Agni-II: Agni II is a solid propelled mobile missile with a range of $2000 \mathrm{kms}$ and a payload capacity of $1000 \mathrm{kgs}$ equipped with advanced high accuracy navigation system guided by state-of-art command and control system (Taneja, 2018b). With a reduced payload, the missile is reported to reach targets up to a range of $3500 \mathrm{kms}$. The missile is a two-stage missile unlike the Agni-I that was a single stage missile. The Agni-II also is equipped with Post Boost Vehicle (PBV) that could be integrated into the missile's reentry vehicle (Business Standard, 2017). The booster stage is more powerful than that of Agni-I as it uses the same booster of the Polar Satellite Launch Vehicle (PSLV). The newer Agni-II missiles use side thrust motors instead of fins as used in the older Agni-II versions and a combination of inertial navigation and GPS in its guidance system.

Agni-III: the Agni-III missile has a range of $3000 \mathrm{kms}$ and a payload capacity of 1.5 tons. It is a two-stage solid propelled ballistic missile (Business Standard, 2017a). The missile is reported to be shorter and wider and capable of carrying a heavier warhead than Agni-I and Agni-II missiles. The missile is both road and rail mobile. Chromium coating on the missile provides the missile with increased range. The missile achieves greater accuracy due to the re-entry vehicle using imaging infra-red or active seekers. In fact, the missile is considered to be one of the most accurate missile systems in the world (Army Technology, 2018).

Agni-IV: like the other Agni versions, Agni-IV missile is nuclear capable with a range of $4000 \mathrm{kms}$ and is expected to be a deterrence against China. The missile uses jam proof ring laser gyroscope for navigation and has features to correct and guide itself for in-flight disturbances. The missile also has micro navigation system- all these features providing the missile with greater accuracy (Bagia, 2017). 
Agni-V: the Agni-V is reported to have a range of $5000 \mathrm{kms}$ though there are views that the missile has an inter-continental range exceeding above $5500 \mathrm{kms}$. Though the Agni- $\mathrm{V}$ is the longer range version of the Agni series, the missile has far advanced navigation and guidance system as well as a warhead and engine (The Times of India, 2018). The navigation system is supported by a unique fault tolerance software installed in the missile. The carbon-carbon composite heat shield is meant to protect the payload and maintains the temperature inside the missile below 50 degrees Celsius (Hindustan Times, 2016). The missile is planned to become an all-composite missile that would be much lighter than the older version (Shukla, 2016).

The missile can be canister launched. This provides the missile with lesser preparation time to launch as compared to 'open configuration test'. The missile is highly reliable with a longer shelf-life. Unlike the other versions of the Agni missile, the Agni-V is a three-stage solid propelled ballistic missile. There are assumptions that the missile may be fitted with multiple independently targetable re-entry vehicles (MIRVs) as well as with maneuverable re-entry vehicle (MaRV). Both technologies being developed by the DRDO. The missile is expected to be inducted in December after another pre-induction test. The missile would be capable of reaching targets in important cities in China like Beijing and Shanghai to name a few (Live Mint, 2018). At the moment, the government plans to restrict itself with a $5000 \mathrm{~km}$ range missile but strategic compulsions and requirements could coerce India to seek for longer ranges.

\section{Global View of the Agni System}

The Agni series and the conduction of the flight tests have always been a concern for the international order. But the West today raises lesser concerns on test-firing and only requests for restraint. However, the Agni-V targeted against China did raise concerns in China and they voiced their discontent over the missile flight tests. The first time that India test-fired the Agni-V missile in 2012, the then China's Foreign Ministry Spokesperson, Liu Weimin stated, "China and India are both emerging powers. We are not rivals, but cooperative partners"(Parthasarathy, 2017). He further stated, 
"China always maintains that preserving the strategic balance and stability in South Asia is conducive to peace and prosperity of regional countries and beyond"(Roy, 2017). However, amid these soft tones, in 2012, China maintained a stern view on the Agni-V, and a state run daily, Global Times also reported, "India was being swept up by missile delusion" and that China's neighbours could never win an arms race with China (Burke, 2012). In 2017, China's state run Global Times accused India of violating UN restrictions on range of missiles over the Agni-IV test and instead claimed that Pakistan should also be allowed the same privileges (The Economic Times, 2018b). The daily also claimed, "if western countries accept India as a nuclear country and are indifferent to the nuclear race between India and Pakistan, China will not stand out and stick rigidly to those nuclear rules as necessary." At the same time, the daily further stated, "New Delhi understands that it does little good to itself if the Sino-Indian relations are ruined by any geopolitical tricks" (The Express Tribune, 2017).

The United States that views India as a strong partner in the Indian Ocean Region (IOR) to counter China's growing influence also refrained from criticising India's 2012 Agni-V test and instead applauded India's non-proliferation efforts then (Rajghatta, 2012). This came as a stark difference between how the US viewed India's missile capabilities from the early 2000s and now. In 2003, when India tested the shorter range Agni-I version, the United States criticised India, "We think tests like this contribute to a charged atmosphere, make it harder to prevent a costly and destabilising nuclear arms race" (The Tribune, 2003).

Pakistan on the other hand reacted to Pakistan centric Agni tests with tit-for-tat tests. For instance, when in 1999, India tested its Agni-II missile, Pakistan followed suit by testing the Ghauri missile followed by the Shaheen-I missile (Chengappa, 1999). In 2003, Pakistan's then Information Minister, Shaikh Rashid claimed the Agni tests to be 'sick war hysteria' at the same time warning India that such tests conducted by India would not help New Delhi to "establish its supremacy in the region" (Chengappa, 2003). Prior to this, in 2001, Pakistan reacted to Agni-II missile criticising India, "India's nuclear ambitions, which are clear from its draft nuclear doctrine announced in 1999, have a destabilising effect on the 
region" (BBC, 2001). In fact, just after India's testing of Chinacentric Agni missiles, Pakistan in March 2018, acquired a powerful missile tracking system from China that is expected to speed up Pakistan's ability to develop MIRV technology.

\section{Agni and Nuclear Deterrence}

That Agni constitutes the backbone of India's land-based nuclear deterrence just like the Shaheen category ballistic missiles for Pakistan and the Dong Feng category missiles for China. The Shaheen is a category of solid propelled ballistic missile and more advanced than the liquid propelled obsolete Ghauri missiles. Pakistan has developed a longer range version of the missile also that can reach targets up to $2750 \mathrm{kms}$ putting India's naval assets in Andaman and Nicobar Islands under threat. At the same time, China too has shifted its focus from liquid-fuelled ballistic missiles to solid fuelled ones for easier survivability and mobility. China is also working on missile defence systems as well as sophisticated offensive weapons like MIRVs, MaRVs and also hypersonic glide vehicles (HGVs). HGVs are hypersonic weapon systems that could be mounted atop a ballistic missile that would not only enable the missile to deliver payload at a faster pace but also evade the adversary missile defence system.

Solid propulsion systems, use of increased stages to increase ranges, advanced guidance and navigation system equipped with the missile, easy mobility- all these characteristics in a missile make the system more credible and reliable thereby strengthening India's strategy of 'credible minimum deterrence.' Mobility makes the missiles more easily survivable to enemy attack thereby strengthening their ability to launch 'counter/second strike' vis-àvis adversaries.

The concept of credibility also has less to do with how credible India feels its nuclear deterrence is and more to do with how credible the adversaries feel about India 's nuclear deterrence. With two neighbours with nuclear capability, India needed to have nuclear weapons delivery systems that could not only carry nuclear warheads but also be able to successfully deliver the same despite enemy defence by denial mechanisms. For instance, canister 
launched missiles are more agile and capable of dodging enemy radars and also spy satellites (The New Indian Express, 2018b). Solid propulsion missile systems are also more difficult to intercept than liquid propulsion system. In addition, solid propulsion system makes launch easier thereby, enhancing the capability of the missile to be launched in a short time. Use of decoys in missiles like AgniIII version further makes them difficult to be intercepted. Though it is not clear if Agnis would be based in silos also, there is a possibility that a humble number of missiles are silo-based with dummy silos too to evade missile attacks. It is also possible that over the years, India has also hardened the silos to avoid the enemy from attacking and destroying the missiles kept in the silos.

India and China have been in the past involved in stand-off crises, and the Dokhlam stand-off is one such example. It is crucial for India to develop deterrence against China. China though has adopted a policy of 'no-first-use', such a policy does not apply to territories that China considers to be a part of its own territory. This has been with Taiwan and India's Arunachal Pradesh as they are considered to be a part of China's own territory. In addition, the then Air Chief in 2017 raised concerns on China's economic and military ties with Pakistan and India's neighbours, rapid infrastructural growth in Tibetan Autonomous Region (TAR) and China's venture into Gwadar port (PIB, 2017). Agni-V is not just a weapon that strengthens India's nuclear deterrence but also can be a weapon that can prove its mettle in coercive diplomacy vis-à-vis China (Ghoshal, 2018).

\section{Issues and Problems}

The operational capability of a missile can only be strengthened when all the Agni category missile systems continuously undergo flight tests. Only then would the technical hazards pertaining to the missile systems be well fathomed and dealt with. For instance, in 2017, the Agni-II flight test experienced failure due to technical hazards (Hindustan Times, 2018). What was more of a concern is the fact that the missile failed to meet all parameters even after being in years of service. These are technical hiccups that India needs to deal with in order to improve its nuclear deterrent capability vis-à-vis Pakistan as well as China. 
In addition, while canister-launch missile systems could enhance India's ability to launch counter-strike against adversaries, the same system could make nuclear deterrence destabilising as canister launched missile would indicate that missiles are ready for deployment in their mated form- that is warheads are mated with their delivery systems. As of now, India's nuclear warheads are not mated with their delivery systems and India follows a posture of 'recessed deterrence.' At the same time, Indian military starkly draws a distinction between deployment and induction and views the former as a wartime arrangement and the latter to be a peacetime arrangement and carefully uses the word 'induction' for the same. Mated Agni-V missile could jeopardise this distinction between wartime and peace time arrangements and further endanger strategic stability. In fact, in 2003, the then President of Pakistan, Parvez Musharraf had ruled out any possibility of accidental nuclear war on grounds that Pakistan's nuclear warheads were not mated with delivery systems, "This is not a Warsaw Pact or NATO situation where warheads and missiles were ready for fire with a button in hand. There is no button in our case. Missiles and warheads are not permitted together. There is a geographical separation between them. One has to go up the escalation ladder to come to the stage of pressing of the button" (The Tribune, 2003).

However, the threat of unauthorised use of such weapons systems is less as India already follows a 'no-first-use' doctrine and due to the virtue of the written doctrine, would not be using the nuclearcapable missile unless adversaries have used nuclear or chemical or biological weapons against it. Also, MIRVs are according to Cold War literature, first-strike weapon systems while India has adopted a policy of 'no-first-use'. Hence, New Delhi would need to ensure that it's political and strategic signalling of the MIRVs are well fathomed by adversaries. India needs to convey efficiently to China and Pakistan that MIRVs would be used as a credible 'counterstrike' weapons and not as a first-strike weapon system.

Not only for nuclear deterrence but also a country's soft power is reliant on its hard power prowess. India has been vying for the United Nations Security Council (UNSC) permanent membership seat and while economic growth and economic development play a 
crucial role in determining this, hard power prowess also adds to the possibility.

\section{Does Agni Pose a Threat to the United States?}

The range of Agni-V does not pose any threat to the mainland United States. However, the missile can reach targets in the IndoPacific Region but India's missile systems are not targeted against any country. The United States and India have formed strong partnerships and are crucial partners in the Indo-Pacific Region to counter China. Today India is a member of the Quadrilateral Dialogue (QUAD) including other members like the United States, Japan and Australia to check the growing influence of China in the region. China's long-range missile systems could easily target US forward bases in the Asia Pacific region and can also reach Japan and Australia. This is probably the reason why the United States realised the importance of including India as a partner. In fact, as has been mentioned earlier, the United States have had a change in how they viewed India's missile development programs and nuclear capability in the last few years, and have also granted the Nuclear Suppliers' Group (NSG) waiver to India despite India not being a member to the Non Proliferation Treaty (NPT).

New Delhi, of course, has been careful to maintain that it does not view QUAD as a group intended against any specific country evident from Prime Minister Narendra Modi's statement, "India does not see the Indo-Pacific region as a strategy or as a club of limited members. Nor as a grouping that seeks to dominate. And by no means do we consider it directed against any country... But our friendships are not alliances of containment" (Patranobis, 2018).

\section{Agni and Credible Minimum Deterrence}

While Agni surely enhances India's credible minimum deterrence posture, it cannot strengthen the posture alone. Agni only constitutes for India's land-based nuclear deterrence and to ensure that 'credible minimum deterrence' is indeed credible, India would also need to equally focus on aerial and sea-based nuclear delivery 
platform- together the three legs would enable India to effectively launch counter and second strike vis-à-vis adversaries.

In addition, missile systems especially land-based systems would also need to be protected from enemy attacks. While road and rail mobility are options, India is also working on ballistic missile defence (BMD) system to intercept incoming enemy missile systems. Though the system is mostly to protect counter-value targets, New Delhi should concentrate on protecting counter-force targets including land-based missile systems. At the same time, Agni with MIRVs as mentioned before can raise concerns in adversaries' minds that India may have adopted 'first-use' policy in its nuclear doctrine. In addition, BMD can also be used both as an offensive and defensive system. For instance, adversaries can be concerned that India may use its offensive missile capabilities like Agni to launch a 'first-strike' on their nuclear forces and use its BMD system to prevent adversaries' missile systems to launch a counter-attack on India's nuclear and conventional capabilities. However, India needs to clearly elaborate its BMD posture in order to avoid any confusion and state that the BMD would be deployed to strengthen India's 'no-first-use doctrine.'

\section{Conclusion}

It is not clear if Agni would be used as a counter-strike or secondstrike weapon system. Whether the system is used for counterstrike or second-strike, India would continuously need to conduct flight tests of the Agni systems to check their operational readiness. These tests need to be conducted on a regular basis during morning, evening or night. Also, training a military personnel to launch the missile at any time of the day whenever the need may arise is of prime importance. Operational readiness of missile systems would strengthen India's credible minimum deterrence posture and promote these weapon systems as weapons of peace rather than war-fighting weapons. While Agni-VI has been speculated, the government has denied any such efforts or programmes being carried out by India. However, should India's strategic compulsion coerce India to develop so, New Delhi surely would go ahead with such capability. 


\section{References}

Arms Control Association. (1999). India, Pakistan test new missiles: U.S. urges restraint. Retrieved from https:// www.armscontrol.org/ print/476

Army Technology. (2018). Agni ballistic missile system. Retrieved from https:// www.army-technology.com/projects/agniballisticmissile/

Auner, E. (2012). India announces successful Agni-5 test. Arms Control Association. Retrieved from https://www.armscontrol.org/ act/ 2012_05/India_Announces_Successful_Agni_5_Test

Bagia, P. (2017). Nuclear-Capable Agni-IV missile tested successfully: 5 facts. NDTV. Retrieved from https://www.ndtv.com/ indianews/nuclear-capable-agni-iv-missile-tested-successfully-5-facts1644166

BBC. (2001). Indian missile test angers Pakistan. BBC News. Retrieved from http://news.bbc.co.uk/2/hi/south_asia/1121731.stm

Bobb, D. (1989). Agni: India successfully launches its first intermediate range ballistic missile. India Today. Retrieved from https:// www.indiatoday.in/magazine/special-report/story/19890615-agniindia-successfully-launches-its-first-intermediate-range-ballisticmissile-816170-1989-06-15

Burke, J. (2012). India's missile fails to rattle China. The Guardian. Retrieved from https://www.theguardian.com/world/2012/apr/19/india-missilechina-agni-v

Business Standard. (2017, May 4). India successfully test fires nuclearcapable Agni-II ballistic missile. Retrieved from https:// www.business-standard.com/article/news-ani/india-successfullytest-fires-nuclear-capable-agni-ii-118022000228_1.html

Business Standard. (2017a, April 27). Agni-III missile successfully testfired off Odisha Coast. Retrieved from https://www.businessstandard.com/article/current-affairs/agni-iii-missile-successfullytest-fired-off-odisha-coast-117042700505_1.html

Chengappa, R. (1999). Pakistan's reply to India's testing of Agni-II intensifies deadly nuclear missiles race. India Today. Retrieved from https:/ / www.indiatoday.in/magazine/defence/story/19990426pakistans-reply-to-indias-testing-of-agni-ii-intensifies-deadly-nuclearmissiles-race-780755-1999-04-26

Chengappa, R. (1999). India puts Nuke arsenal under civilian control, but situation worryingly unclear in Pak. India Today. Retrieved from 
https://www.indiatoday.in/magazine/defence/story/20030120-india-putsnuke-arsenal-under-civilian-control-but-situation-worryingly-unclear-inpak-793556-2003-01-20

Ghoshal, D. (2018). How Agni-V induction will enhance India's nuclear deterrence. The Week. Retrieved from https:// www.theweek.in/news/india/2018/08/22/How-Agni-5-inductionwill-enhance-India-nuclear-deterrence-china.html

Hindustan Times. (2018). Test fire of Agni-II missile fails to meet all the desired parameters. Retrieved from https:/ www.hindustantimes.com/ india-news/test-fire-of-agni-ii-missilefails-to-meet-all-the.desired-parameters/story5QOZsAJbE8F8vMALaovjbN.html

Hindustan Times. (2016). India successfully test-fires nuclear-capable Agni-5 ballistic missile. Retrieved from https://www.hindustantimes.com/ india-news/india-set-to-testlaunch-indigenously-built-agni-5-missile-today/storyImTmewEjlvCRrMrBNxJeXO.html

Live Mint. (2018). India's most potent missile Agni-V to be inducted soon. Retrieved from https://www.livemint.com/ Politics/ VfoupaY23 likA5s4vixvtK/Indias-most-potent-missile-AgniV-to-be-inductedsoon.html

Missile Threat. (2016). Agni-2. Retrieved from https:// missilethreat.csis.org/missile/agni-2/

News 18. (2017). India successfully test fires Agni-III missile. Retrieved from https:/ / missilethreat.csis.org/missile/agni-2/

Pandit, R. (2018). 20 years after Pokhran-II, intercontinental ballistic missile Agni-V on Way. The Times of India. Retrieved from https://timesofindia.indiatimes.com/india/20-years-after-pokhranii-intercontinental-ballistic-missile-agni-v-on-way/articleshow / 64130922.cms

Parthasarathy, G. (2017, Januray 11). Why Agni-V launch fired up China. Business Line. Retrieved from https:// www.thehindubusinessline.com/opinion/why-our-agni-v-launchfired-up-china/article9474120.ece

Patranobis, S. (2018). India's 'Vision' for Indo-Pacific region puts a question mark on 'Quad'. Hindustan Time. Retrieved from https:// www.hindustantimes.com/world-news/india-s-vision-forindo-pacific-region-puts-a-question-mark-on-quad/storyQXA7GJIhKNB7W4NAlkhoBJ.html 
Ghosh, D. (2017). Successfully test launch of Agni-V. Press Information Bureau. Retrieved from https://pibindia.wordpress.com/ 2017/ 01/04/successful-test-launch-of-agni-v/

Prasannan, R. (2015). Secret? Tell it to the press. The Week. Retrieved from https://www.theweek.in/theweek/cover/Abdul-Kalam-and-themedia.html

Rajaraman, R. (2014, July 2). Minimum deterrent and large arsenal. The Hindu. Retrieved from https://www.thehindu.com/opinion/oped/minimum-deterrent-and-large-arsenal/article6167350.ece

Rajghatta, C. (2012, April 20). US Refrains from Criticising Agni-V Test, Praises India's Non-proliferation Record. The Times of India. Retrieved from https://timesofindia.indiatimes.com/india/USrefrains-from-criticizing-Agni-V-test-praises-Indias-non-proliferationrecord/articleshow/12738475.cms

Ranghuvanshi, V. (2016). India tests Agni-V ballistic missile. Defense New. Retrieved from https://www.defensenews.com/ space/ 2016/ 12/ 26/india-tests-agni-v-ballistic-missile/

Rout, H. K. (2010). India test-fires nuclear capable Agni-I missile. The Times of India. Retrieved from https:// timesofindia. indiatimes.com/ india/India-test-fires-nuclear-capable-Agni-I-missile /articleshow/6986753.cms

Roy, D. D. (2017). After China's comment on Agni-V missile test, India's curt response. NDTV. Retrieved from https://www.ndtv.com/indianews/after-chinas-comment-on-agni-v-missile-test-indias-curtresponse-1642498

Shukla, A. (2016). A lighter Agni-5 could be world's most cost effective ICBM. Rediff.com. Retrieved from http://www.rediff.com/ news/ special/agni-5-could-be-worlds-most-cost-effectiveicbm/20161230.htm

Subramanian, T. S. (2017, January 2). Agni-IV missile successfully testfired. The Hindu. Retrieved from https:/ / www.thehindu.com/ news/ national/Agni-IV-missile-successfully-test-fired/article16977450.ece

Taneja, R. (2018a). India successfully test fires nuclear capable ballistic Agni-1 missile: 10 facts. NDTV. Retrieved from https:// www.ndtv.com/india-news/india-successfully-test-fires-agni-1missile-10-facts-1809270

Taneja, R. (2018b). India successfully test-fires nuclear capable ballistic Agni-II missile: All you need to know. NDTV. Retrieved from https:/ / www.ndtv.com/india-news/agni-ii-missile-successfully-testfired-from-india-all-you-need-to-know-1814867 
The Economic Times. (2012). India cut Agni V range from 9000 km-5000 km under NATO pressure: Chinese media. Retrieved from https:// economictimes.indiatimes.com/news/politics-and-nation/india-cutagni-v-range-from-9000-km-to-5000-km-under-nato-pressure-chinesemedia/articleshow/12829044.cms

The Economic Times. (2018b). India's agni long-range missiles broke UN limits: Chinese media. Retrieved from https:// economictimes. indiatimes. com/news/defence/indias-agni-long-range -missilesbroke -un-limits -chinese-media/ articleshow/ 56349807.cms

The Economic Times. (2013). Agni Series: India's ballistic missile. Retrieved from https://economictimes.indiatimes.com/ slideshows/ science-technology/agni-series-indias-ballistic-missiles/slideshow / 23288563.cms

The Express Tribune. (2017). China will not sit still. State-run daily responds to India missile test. Retrieved from https:// tribune.com.pk/ story/ 1285400/china-will-not-sit-still-state-rundaily -responds-india-missile-test/

The Hindu. (2018). Agni-I missile with nuclear weapon carrying capability flight tested successfully. February 6. Retrieved from https://www.thehindu.com/news/national/nuclear-capable-agni-imissile-test-fired-successfully/article22665930.ece

The New Indian Express. (2018b). Agni-v success boosts India's nuclear deterrence. Retrieved from http://www.newindianexpress.com/ states/ odisha/2018/jun/04/agni-v-success-boosts-indias-nucleardeterrence-1823440.html

The Times of India. (2018). India successfully test fires nuclear capable Agni-5. Retrieved from https://timesofindia.indiatimes.com/ india/india-successfully-test-fires-nuclear-capable-agni-5/ articleshow/ 64434530. cms

The Tribune. (2003). Musharraf rules out accidental N-war. Retrieved from https:/ / www.tribuneindia.com/2003/20030111/world.htm\#1

The Tribune. (2003). Missile test adds to 'Charged Atmosphere'. Retrieved from https:/ / www.tribuneindia.com/2003/20030111/world.htm\#6 